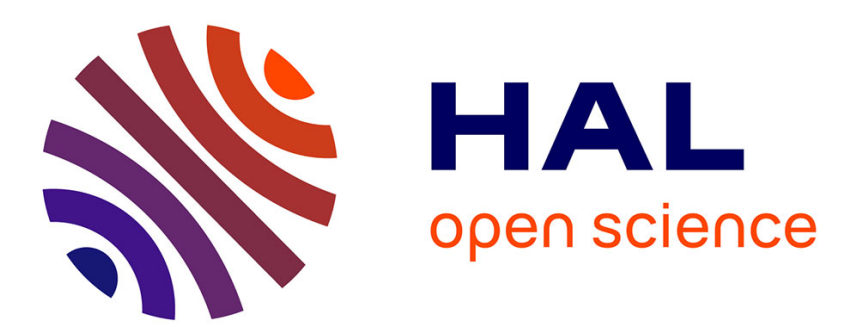

\title{
How summit calderas collapse on basaltic volcanoes: New insights from the April 2007 caldera collapse of Piton de la Fournaise volcano
}

\author{
Laurent Michon, Nicolas Villeneuve, Thibault Catry, Olivier Merle
}

\section{- To cite this version:}

Laurent Michon, Nicolas Villeneuve, Thibault Catry, Olivier Merle. How summit calderas collapse on basaltic volcanoes: New insights from the April 2007 caldera collapse of Piton de la Fournaise volcano. Journal of Volcanology and Geothermal Research, 2009, 184 (1-2), pp.138-151. 10.1016/j.jvolgeores.2008.11.003 . hal-00450273

\section{HAL Id: hal-00450273 \\ https://hal.science/hal-00450273}

Submitted on 24 Oct 2016

HAL is a multi-disciplinary open access archive for the deposit and dissemination of scientific research documents, whether they are published or not. The documents may come from teaching and research institutions in France or abroad, or from public or private research centers.
L'archive ouverte pluridisciplinaire HAL, est destinée au dépôt et à la diffusion de documents scientifiques de niveau recherche, publiés ou non, émanant des établissements d'enseignement et de recherche français ou étrangers, des laboratoires publics ou privés. 


\title{
How summit calderas collapse on basaltic volcanoes: New insights from the April 2007 caldera collapse of Piton de la Fournaise volcano
}

\author{
Laurent Michon $^{\mathrm{a}, *}$, Nicolas Villeneuve ${ }^{\mathrm{b}}$, Thibault Catry ${ }^{\mathrm{a}, \mathrm{c}}$, Olivier Merle ${ }^{\mathrm{a}, \mathrm{d}}$ \\ a Laboratoire GéoSciences Réunion, Université de la Réunion, Institut de Physique du Globe de Paris, CNRS, UMR 7154 - Géologie des Systèmes Volcaniques, \\ 15 avenue René Cassin, 97715 Saint Denis, France \\ b Institut de Recherche pour le Développement, US 140, BP172, 97492 Sainte-Clotilde cedex, France \\ ' Dipartimento di Scienze della Terra e Geologico Ambientali, University of Bologna, Piazza di Porta S. Donato 1, 40127, Bologna, Italy \\ ' Laboratoire Magmas et Volcans, UMR 6524 CNRS-IRD-Université Blaise Pascal, 5 rue Kessler 63038 Clermont-Ferrand, France
}

\begin{abstract}
A B S T R A C T
In April 2007, Piton de la Fournaise volcano experienced a caldera collapse during its largest historical eruption. We present here a structural analysis both of the caldera and the surrounding area, and precise GPS data recorded with a dense GPS network specifically dedicated to the analysis of deformation related to the summit collapse structures. Despite a collapse of more than $300 \mathrm{~m}$ in the central zone, the geometry of the new caldera is similar in map view to that of the pre-existing collapsed structure, which was formed from the coalescence of several pit craters. The caldera shows an asymmetric inner geometry with sub-vertical walls in the NW quadrant and steep scarps composed of inward tilted blocks in the southern half. The presence of preserved polished surfaces on the lower part of the sub-vertical scarp indicates that it corresponds to the caldera north-western ring fault. The April 2007 caldera collapse led to the development and the reactivation of concentric fractures on the caldera rim, mostly along the southern limit of the caldera. GPS data show that fractures result from radial extensional stresses that are restricted within the first tens of meters of the caldera edge. GPS data also reveal that the caldera collapse was coeval with a centripetal deflation, whose magnitude is largest along the southern half of the caldera. The displacements recorded by GPS result from both a general deflation, due to magma withdrawal from Piton de la Fournaise's summit magma chamber, and additional local effects related to the caldera collapse. Comparison of the caldera collapses at Piton de la Fournaise, Miyakejima and Fernandina reveals striking similarities, with cyclic seismic signals accompanying small-scale deflation-inflation cycles. This strongly suggests a common mode of collapse. Hence, we propose a unifying model of caldera collapse in basaltic setting, in which the inward deflation due to magma withdrawal from the magma chamber prevents the collapse of the caldera roof until the gravitational stress acting on the rock column above the magma chamber exceeds the shear strength along pre-existing ring faults. The downward displacement stops when the pressure increase into the magma chamber is able to again sustain the rock column. The succession of (1) inward deflation that prevents the collapse, (2) collapse due to gravitational stress and (3) stopping of the downward motion is repeated many times. The frequency of the cycles is influenced by the rate of magma withdrawal and by the amount of intrusion of magma along the ring faults.
\end{abstract}

\section{Introduction}

Basaltic volcanoes present summit calderas, whose formation is related in most cases to lateral magma migration from a shallow magma reservoir (e.g. MacDonald, 1965). Observations of basaltic calderas worldwide, and the few recorded collapse events, show common structural characteristics and collapse mechanisms, which can be summarised as follows. First, caldera collapses are contemporaneous with a periodic seismicity underlined by either a very-long-

\footnotetext{
* Corresponding author. Tel.: +33 2622629382 04; fax: +33262 262938266 . E-mail address: laurent.michon@univ-reunion.fr (L. Michon).
}

period seismic signal (Miyakejima in 2000, Kumagai et al., 2001) or large earthquakes, i.e. between $M_{\mathrm{s}} 4.4$ and 5.5 (Fernandina in 1968, Simkin and Howard, 1970; Filson et al., 1973). Despite differences in the type of seismic signal, their periodicity has been interpreted in the same way, i.e. an intermittent collapse of the rock column into the magma chamber (Simkin and Howard, 1970; Filson et al., 1973; Kumagai et al., 2001). Questions remain on the source of the periodicity which is interpreted as being controlled either by the constant magma outflow (Kumagai et al., 2001), by an irregular geometry of the bottom of the collapsing rock column (Filson et al., 1973) or by regular stress built up along the caldera fault, which is sporadically relieved by movement along the ring fault (Simkin and 
Howard, 1970). Second, analyses of the surface deformation have long-revealed that collapses are coeval with centripetal deflation of the edifice (Wilson, 1935; Ryan et al., 1983). Both deformations, i.e. the collapse and the inward subsidence, result from pressure decrease within the magma chamber and/or the plumbing system (Mogi, 1958; Walsh and Decker, 1971; Ito and Yoshioka, 2002). Third, collapse calderas often show peripheral concentric extensional fractures hundreds of metres from the edge of their caldera rim (Simkin and Howard, 1970; Lénat and Bachèlery, 1990; Troll et al., 2002; Acocella, 2006; Carter et al., 2007). The various authors describe an increase of extension and vertical displacements close to the caldera rim, but their interpretations differ. The changes in rim geometry are thought to result from superficial processes postdating the caldera formation (Acocella, 2006), from extensional stresses related to the centripetal subsidence (Branney, 1995), or from inflation-deflation cycles (Lénat and Bachèlery, 1990).

In April 2007, Piton de la Fournaise volcano experienced a caldera collapse during its largest historical eruption (Michon et al., 2007). We present here the summit deformation accompanying this event. We integrate a detailed analysis of both concentric fractures and intracaldera structures and faults, with high precision GPS data from a dense network implemented surrounding the caldera. Our study benefited from an initial field and GPS campaign carried out in March 2007, a few days before the onset of the eruption and collapse. The GPS network has been reoccupied twice, in May and November 2007, in order to determine the syn-collapse and post-collapse displacements, respectively. This paper aims at determining the relationship between the concentric fractures and the collapse. It also attempts to better understand the collapse mechanism and its relation to eruption dynamics. Finally, it addresses the role of pre-existing structures in the development of a new caldera.

\section{Geological setting}

Piton de la Fournaise volcano is one of the world's most active volcanoes (Lénat and Bachèlery, 1987). At the edifice scale, it is characterised by two NE and SE rift zones and an E-W U-shaped caldera formed around 4.5 ka ago (Bachèlery, 1981; Fig. 1a and b). The volcanic activity is concentrated in the upper part of the U-shaped structure, the Enclos caldera, where the accumulation of volcanic products has built up a steep central cone (Michon et al., 2009-this issue). Prior to April 2007, the summit of the active cone was cut by two collapse structures: Bory in the west, which is currently inactive, and Dolomieu in the east, the location of the caldera collapse during the large April 2007 eruption (Fig. 1c). Before this collapse, the elongated shape of the pre-existing Dolomieu was the result of the coalescence of several pit craters (Lénat and Bachèlery, 1990; Carter et al., 2007). The largest of these events occurred between 1933 and 1936, during which the eastern half of Dolomieu experienced a $150 \mathrm{~m}$ deep collapse (Fig. 1d; Lacroix, 1939; Bachèlery, 1981). Until 1953, the western part of Dolomieu also suffered recurrent collapses that were accompanied by progressive subsidence of the crater floor. From 1953 the lava accumulated during the frequent summit eruptions and progressively filled the collapse structure, whose outer contour remained unchanged until March 2007, despite the small pit crater collapse in 1986 (Hirn et al., 1991) and a brutal but minor subsidence in 2002 (Fig. 1d; Longpré et al., 2007). It is noteworthy that the August 2006-January 2007 summit eruption created a lava pile of 20-30 m on the Dolomieu floor, filling the crater and overtopping the eastern caldera wall (Michon et al., 2007).

In 1990, a detailed structural analysis of the summit of the active cone revealed a complex network of concentric extensional fractures concentrated around Dolomieu only (Fig. 1d; Lénat and Bachèlery, 1990). It also highlighted the asymmetric distribution of the concentric fractures around the east and west parts of Dolomieu. The eastern rim of Dolomieu was characterised by a few fractures restricted to a $50-80 \mathrm{~m}$ wide zone. In contrast, concentric fractures were scattered within a $200-300 \mathrm{~m}$ wide zone around the western half of Dolomieu. The northern limit of this fracture network coincides with a topographic break-in-slope that corresponds to the hidden boundary of a paleo-pit crater (Lénat and Bachèlery, 1990; Michon et al., 2009-this issue). South of Dolomieu, the Petit Plateau paleo-pit crater, formed around 1911 (Bachèlery, 1981), consists of an independent system of concentric fractures that delimitates the hidden collapsed structure. The age of the overall fracture system is hard to determine. However, the lack of any significant fractures south of the western fracture zones, where the lava emitted by the 1936 and 1956 eruptive fissures covers the surface (Fig. 1d), suggests that fractures in the west predate these eruptions. In the east, the similar distribution of both the limits of the 1933-1936 pit crater and the peripheral concentric fractures supports a temporal relationship between the main collapse event and the development of extension fractures close to the rim. Since 1990, the only significant change in the concentric fracture system was observed during the August 2006January 2007 eruption, during which fractures close to the rim in the south-eastern part of Dolomieu opened of a few tens of centimetres to a few metres. These fractures accommodated the progressive inward tilting of rock panels torn apart from the rim of the collapse structure.

The April 2007 caldera collapse of Piton de la Fournaise occurred during the largest historical eruption, starting on 30th March and ended the 1st May 2007. Although the detailed evolution of the eruption has already been presented (Michon et al., 2007; Staudacher et al., 2009-this issue), we summarise below the main characteristics that allow us to interpret the origin and dynamics of the caldera collapse. On 30th March, a first eruptive fissure opened south-east of the central cone at about $1900 \mathrm{~m}$ above sea level (Fig. 1b). After less than $10 \mathrm{~h}$, the magma emission ceased, whereas the summit seismicity remained at a very high level. The magma emission started anew on 2nd April when an eruptive fissure opened at about $600 \mathrm{~m}$ asl, $7 \mathrm{~km}$ away from the summit (Fig. 1b). The rate at which magma was discharged, which was already large, increased during 5th April contemporaneously with a summit centripetal deflation. The first summit collapse occurred on 5th April at 20:48, contemporary to a magnitude 3.2 volcano-tectonic event (Michon et al., 2007). It was immediately followed by a sudden centrifugal uplift of the caldera rim (Michon et al., 2007; Staudacher et al., 2009-this issue). The collapse also had a striking impact at the eruption site where the seismic signal increased by around $50 \%$. Then, both the seismic signal and the summit displacements began to occur in cycles characterised by an inward deflation accompanied by an increase of the seismic signal, ending with a sharp outward uplift contemporaneous with sudden decrease of the seismicity. The cycle frequency gradually increased from 2 h to 30 min (Michon et al., 2007; Staudacher et al., 2009-this issue). A total of 38 collapse events were distinguished between 5 th April, 20:48, and 7th April, 00:40. First observations of the new caldera, in the afternoon of 6th April, revealed that the 16 first collapses triggered the development of most of the summit collapse caldera (Michon et al., 2007). Disregarding continued spalling of material from the caldera wall, the final geometry of the caldera was attained on 10th April. The eruption continued at a low level until the 1st May 2007.

\section{Summit deformation related to the April 2007 eruption}

\subsection{Structural analysis}

On 6th April, the first observations indicated that the collapse was elongated along an E-W axis and concentrated in the northern part of Dolomieu (see Fig. 4b in Michon et al., 2007). It was bounded by $200-$ 300 m-high subvertical scarps in the east, west and north, and by subsiding terraces in the south. Two annular plateaus corresponding to the pre-existing floor of Dolomieu remained in the E and SW (see Fig. 4 in Michon et al., 2007). 

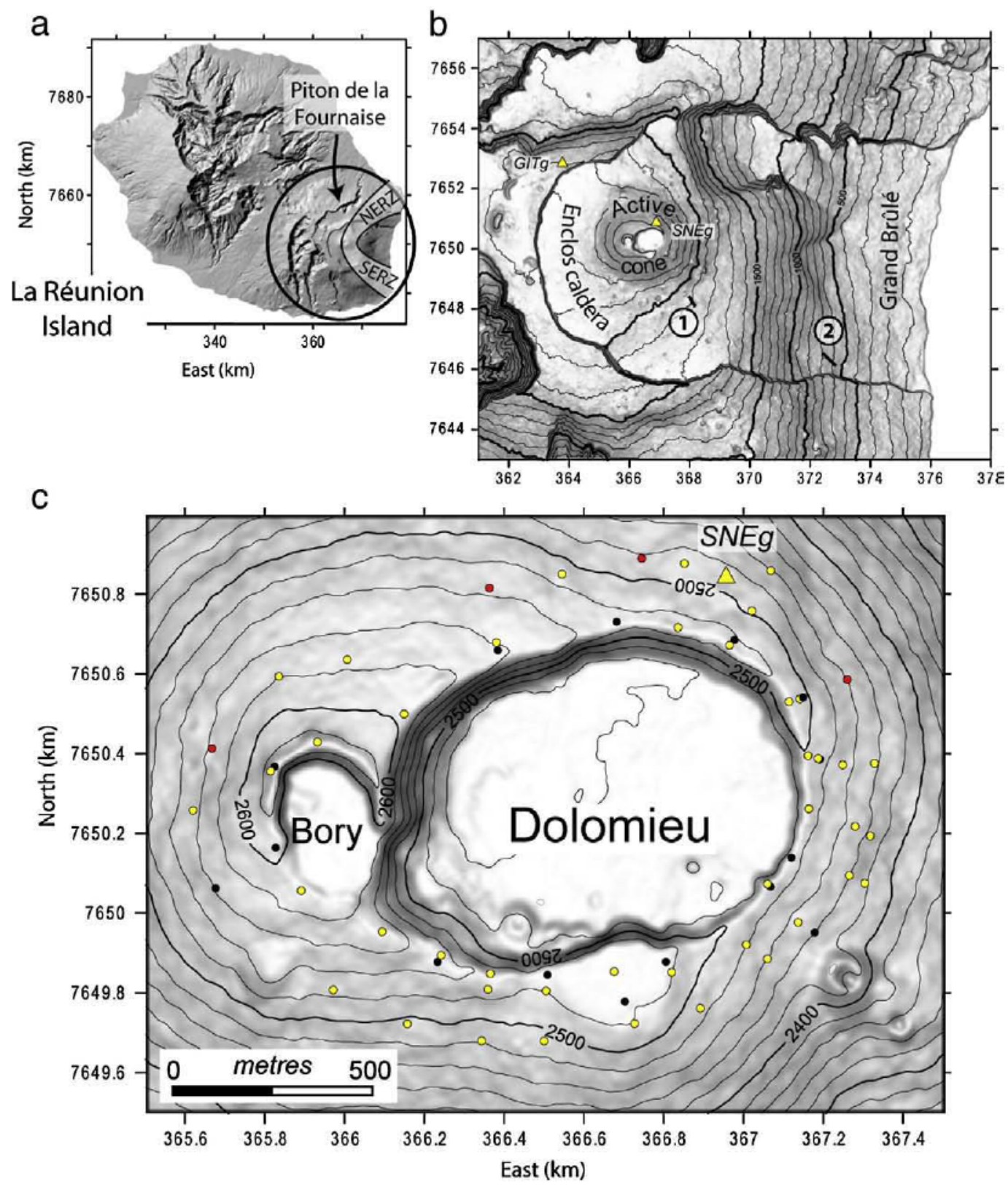

d

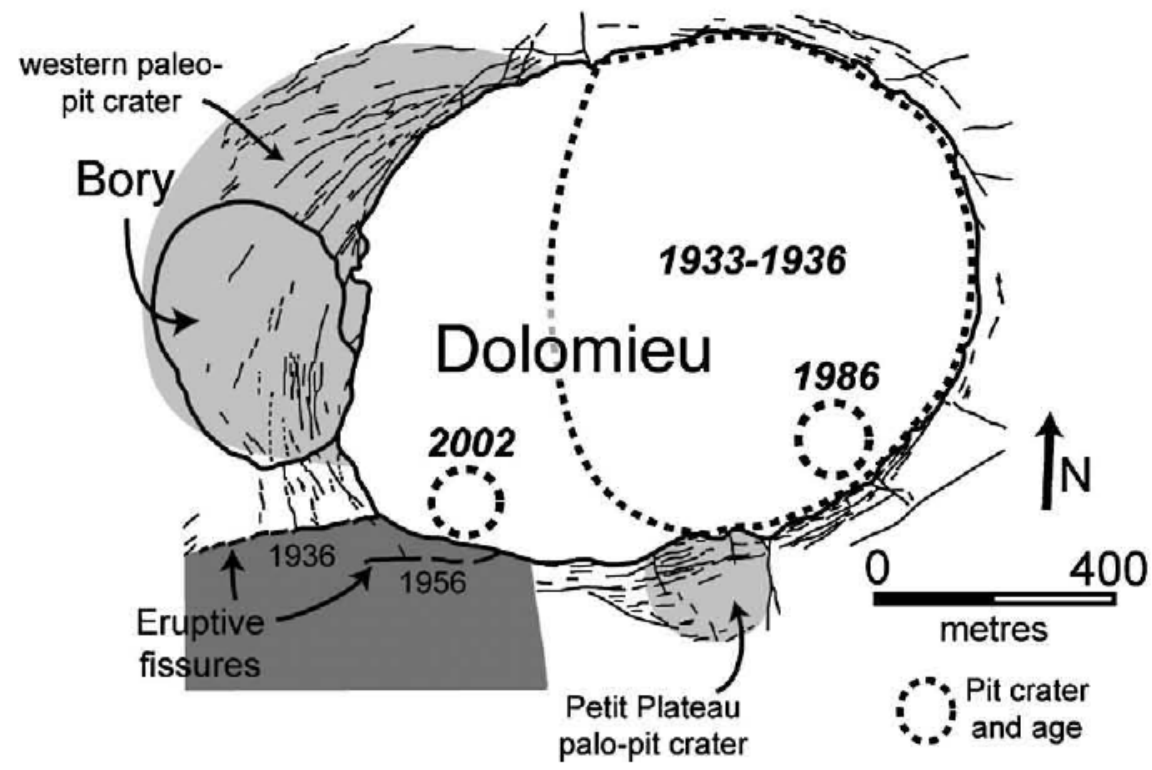


a
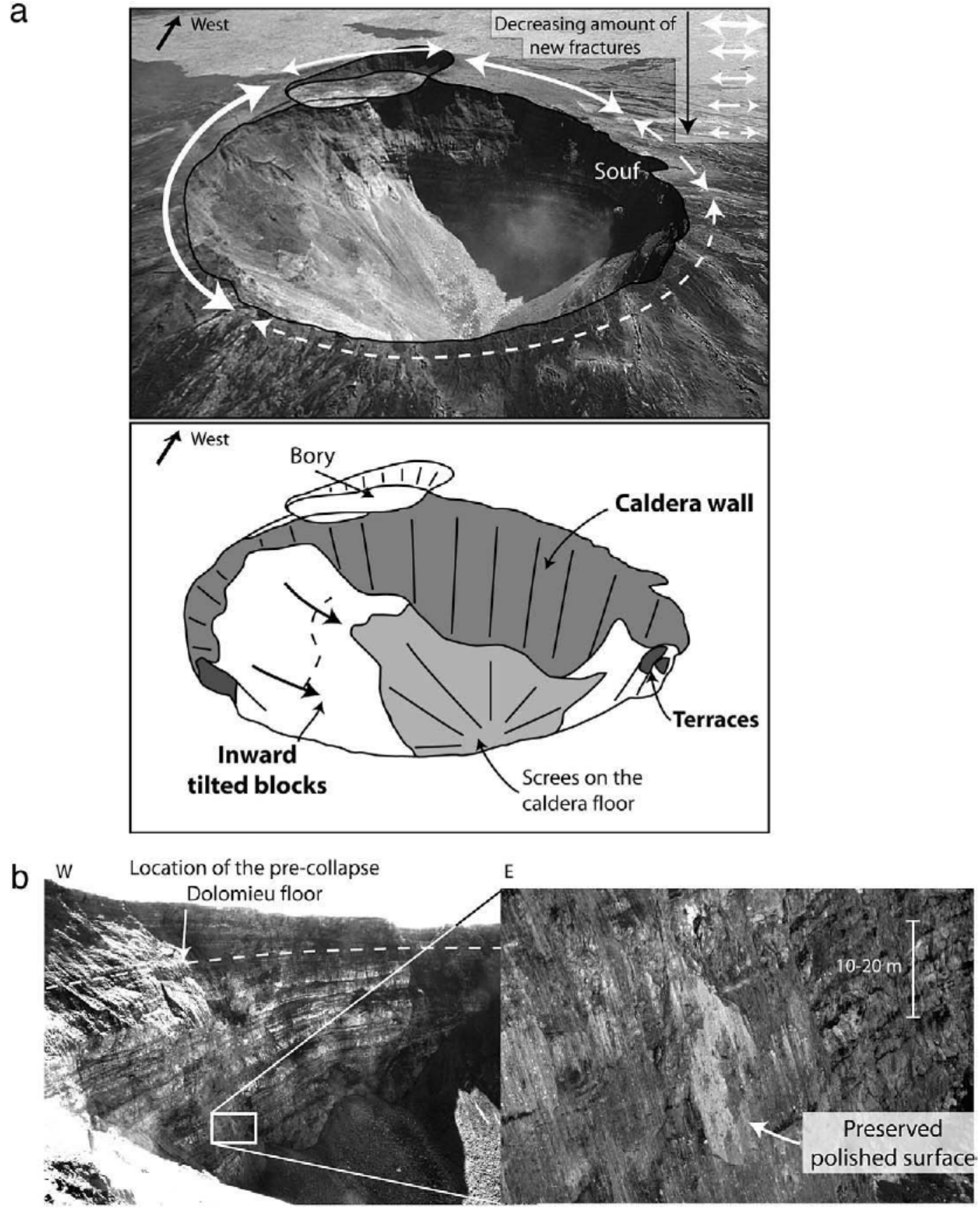

Fig. 2. a - The April 2007 caldera. The maximum depth is located in the northern half of the caldera. Note the differences between the northern and southern caldera flanks. New concentric fractures are represented by arrows. Fractures opened essentially south of the caldera. Souf: Soufrière pit crater. b - View of the north-western caldera wall. Several polished surfaces were preserved few days after the caldera collapse until destruction of this scarp by landslide in May 2007.

At the end of the collapse, on 10th April, the new caldera had a maximum depth of 320-340 m (Michon et al., 2007; Urai et al., 2007) at the location of the initial collapsed structure. The deepest part of the caldera is covered by scree resulting from the frequent rock slides from the caldera walls (Fig. 2a). Two different topographic expressions of the collapse are distinguished. The southern, eastern and north-eastern walls have average slopes of $40-50^{\circ}$, whereas the north- western wall is sub-vertical $\left(70-80^{\circ}\right)$. The distribution of these two distinct geometries coincides with the structure differences observed on 6th April. The north-western caldera flank already existed on 6th April, by which time it was bounding the northern collapse structure. The preservation of polished surfaces, found only on the lower half of this scarp (Fig. 2b), suggests that the north-western caldera wall corresponds to an inward-dipping ring fault. In contrast, the geometry

Fig. 1. a - Location of Piton de la Fournaise volcano on La Réunion Island. b - Location of the eruptive centre within the Enclos caldera. Eruptive fissures opened on March 30 th and April 2nd are located by 1 and 2, respectively. SNEg and GITg correspond to the reference receivers of the summit GPS network. c - Distribution of the benchmarks around the summit collapsed structures of Dolomieu and Bory. Benchmarks measured in March and May 2007 (yellow), in May and November (black) and for both periods (red). $d$ - Fracture network around the summit collapsed structures (after Lénat and Bachèlery, 1990). 


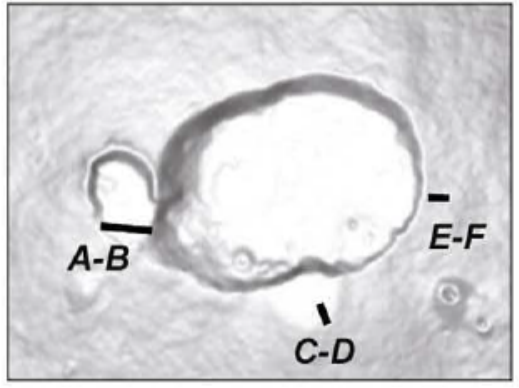

East

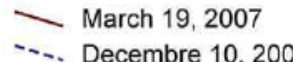

-. Decembre 10,2007

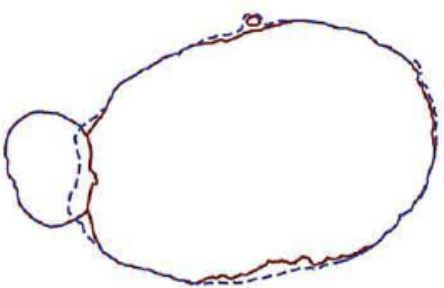

West
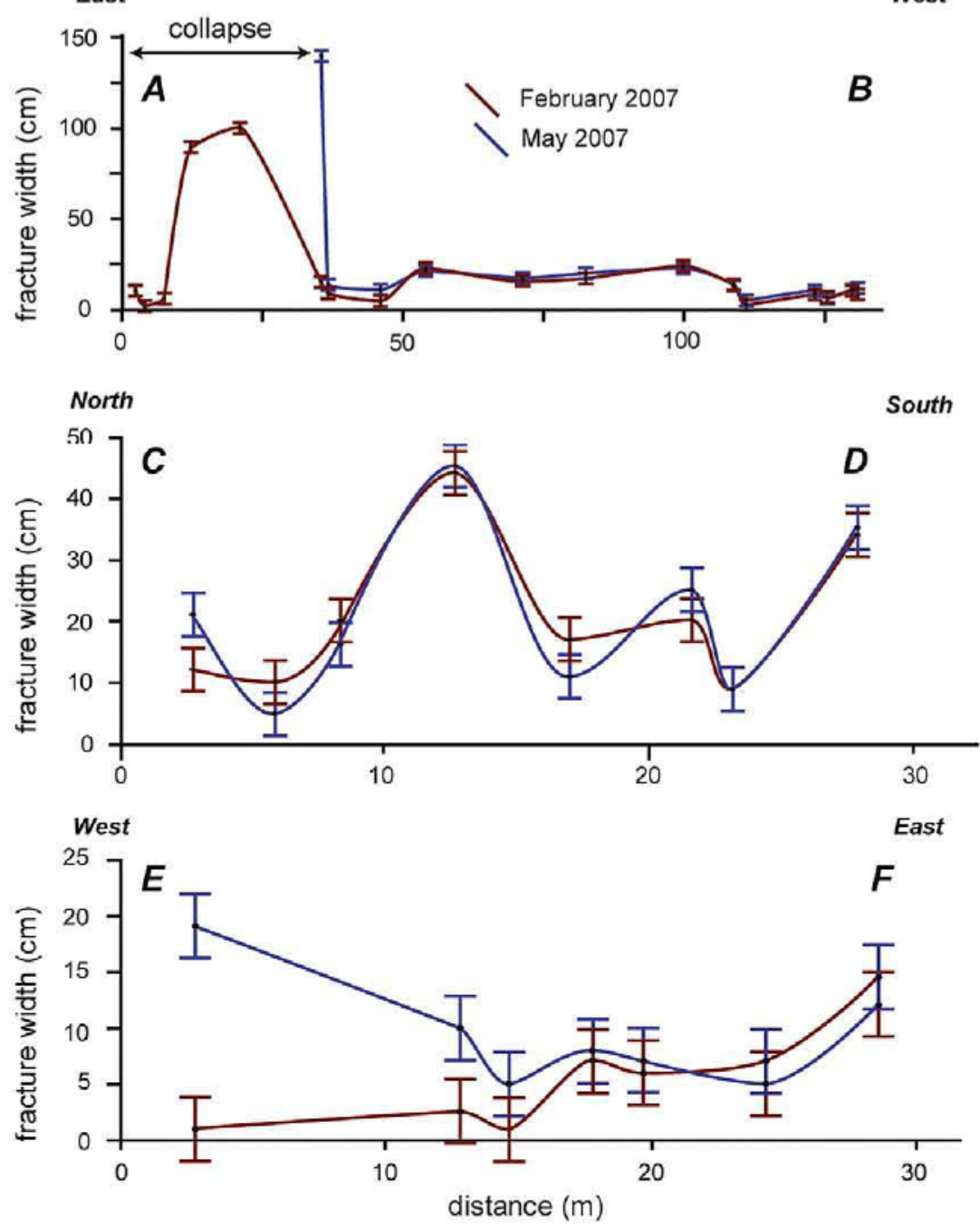

Fig. 3. Contours of the summit structures before and after the caldera collapse. Fracture width along three radial profiles measured in February and May 2007.

of the southern, eastern and north-eastern flanks post-dates 6th April. This likely results from the inward subsidence of the southern and eastern plateaus similar to that observed during the caldera formation at Miyakejima (Geshi et al., 2002).

In map view, Dolomieu was a $1-1.1 \mathrm{~km}-$ long and $0.76-0.80 \mathrm{~km}-$ wide elongated structure before the April 2007 eruption (Fig. 3). The April 2007 caldera collapse constitutes the largest collapse event ever observed at Piton de la Fournaise. However, despite a collapse of several hundreds of metres, the contour of the new caldera did not significantly change. The new caldera widened only a few tens of metres in the north, west and south parts, mostly a few days after the caldera collapse (Fig. 3). The similar geometry of the pre-existing collapse structure and the new caldera, and the lateral growth of the initial collapse up to the pre-existing Dolomieu boundary can be compared to the map view evolution of the caldera collapse at Miyakejima, where the initial caldera grew laterally up to approximately the limit of the pre-existing 2.5 ka-old Hatchodaira caldera (Geshi et al., 2002).

We also showed in Section 2 that, prior to 2007, the rim of Dolomieu was affected by asymmetrically distributed concentric fractures (Fig.1). Three radial profiles were implemented in February 2007 around Dolomieu, at different distances from the caldera edge, in order to determine the potential reactivation of these fractures during collapse events (Fig. 3). The effect of the April 2007 caldera collapse has been evaluated by a reiteration of the profiles in May 2007. Fig. 3, which shows the fracture width before and after the collapse, illustrates the 
influence of the April 2007 caldera collapse in the fracture system. It clearly shows that the collapse reactivated only the closest fractures to the caldera edge, and had no impact away from the edge. The concentration of the deformation is corroborated by the development of a narrow fracture system within the first tens of metres from the caldera edge, the density of which varies laterally. The new concentric fractures are densely distributed around the southern part of the caldera, whereas they are nearly non-existent in the east (Fig. 2a).

\subsection{GPS data}

Since 2001, the deformation of Piton de la Fournaise related to dyke intrusion has been regularly monitored by the GPS network of the Piton de la Fournaise Volcano Observatory (OVPF/IPGP; Peltier, 2007). This network, which is composed of about 80 stainless steel benchmarks cemented around the crater, on the flanks and at the base of the summit cone, accurately measures large scale deformation of the Piton de la Fournaise edifice, but is inadequate to evaluate in detail the summit deformation linked to collapse events. Hence, we implemented a new GPS network in November 2005, specifically dedicated to the structural analysis in a narrow zone around Bory and Dolomieu.

\subsubsection{Methodology}

The new GPS network is composed of 62 benchmarks (geodetic nails fixed into massive lava) installed along 24 radial profiles, and of two permanent receivers of the OVPF/IPGP located at the summit and outside the Enclos caldera (Fig. 1b and c). The position of each point of the network was measured before the eruption (in March 2007), and twice after the eruption (in May and November 2007). This allows the determination of the deformation related to the April 2007 caldera collapse and the residual subsidence following this event. Measurements were performed in differential mode with dual-frequencies receivers (2 Ashtech Zextrem and 2 Trimble NetRS). The SNEg summit receiver of the permanent GPS network of OVPF/IPGP (Fig. 1) was used as reference. Its position was systematically calculated with respect to a stable permanent receiver (GITg) located outside the Enclos caldera. The location of SNEg was precisely measured in static mode during $6 \mathrm{~h}$ with a $1 \mathrm{~s}$ sampling rate. In a way similar to measurements at Merapi volcano (Beauducel et al., 2006), measurements of the benchmarks were performed with a small base line $(<1.5 \mathrm{~km})$, a $1 \mathrm{~s} \mathrm{sampling}$ rate and station on the benchmarks of $3 \mathrm{~min}$. During each GPS campaign, several benchmarks were measured twice with a time interval of several hours in order to take into account not only the instrumental RMS values, but also the handling error. Thus,

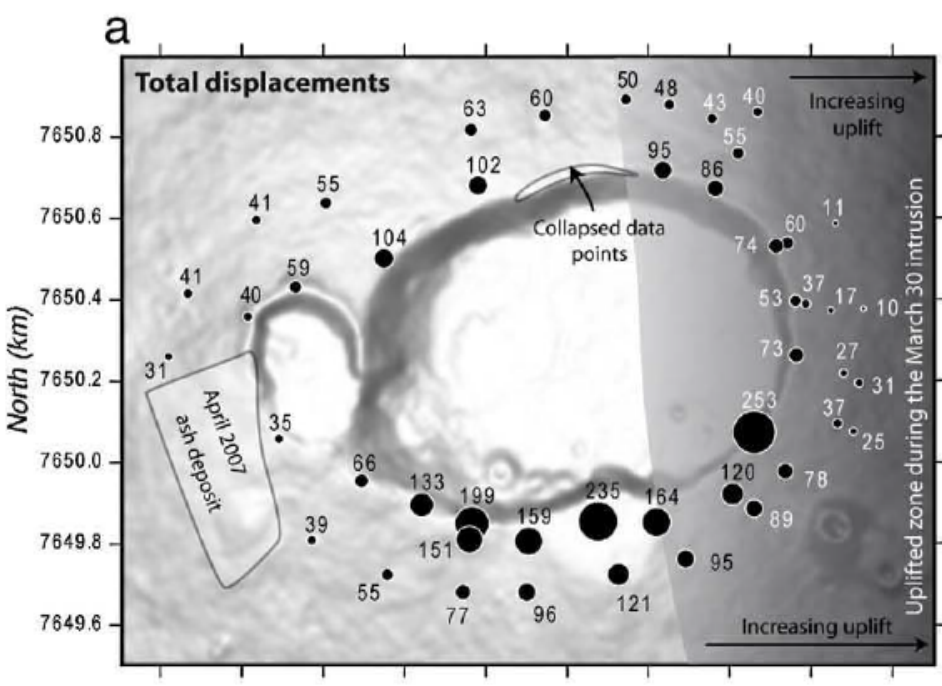

b
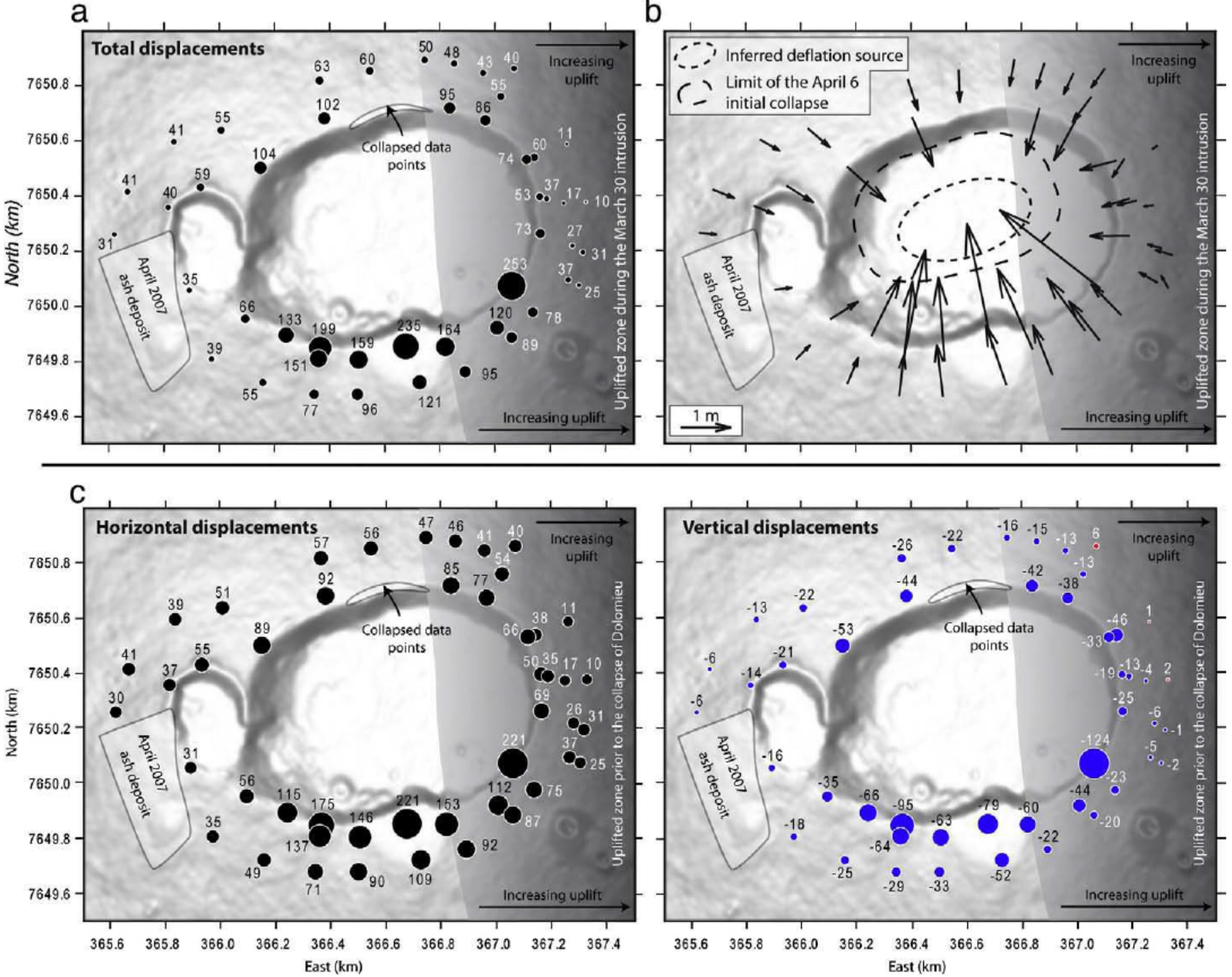

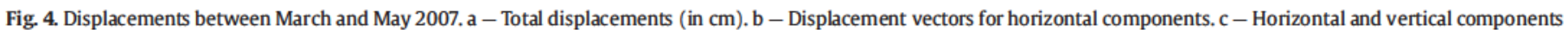
(in $\mathrm{cm}$ ). 

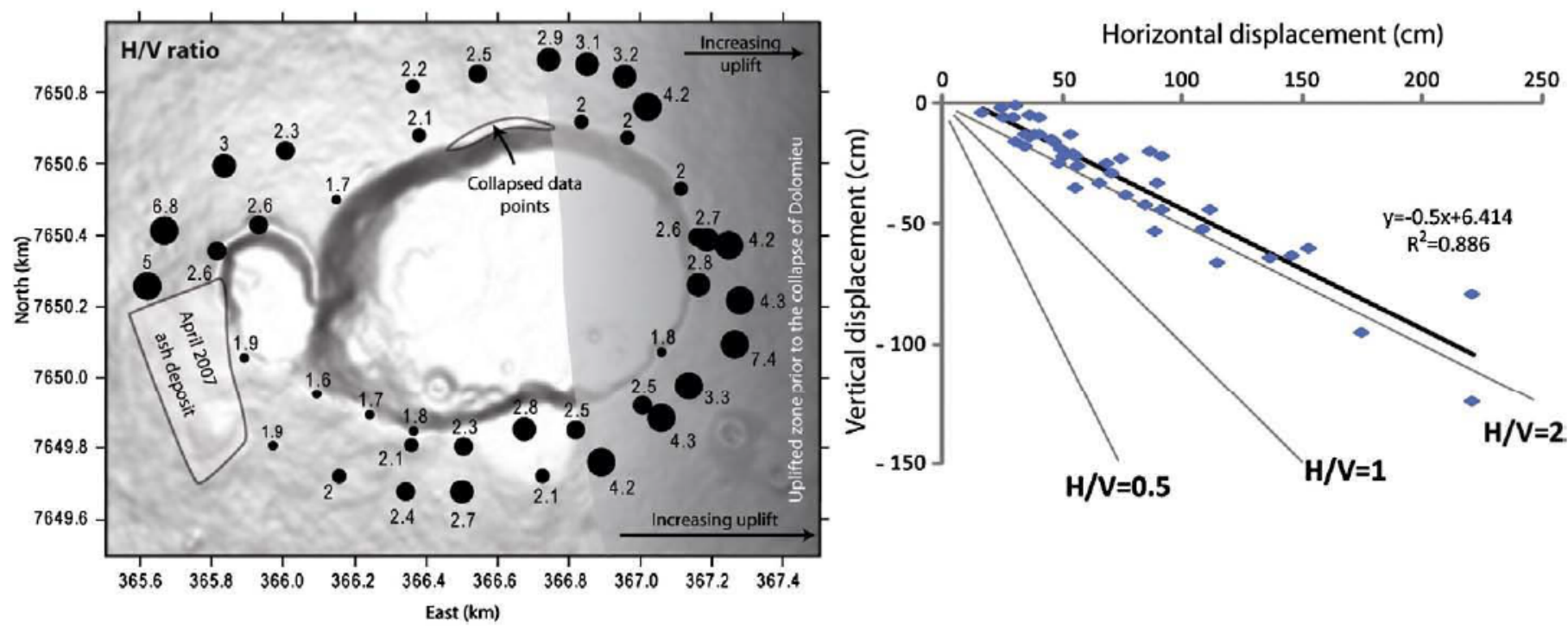

Fig. 5. Horizontal/vertical ratio for the period between March and May 2007. The $H / V$ ratios are linearly organised suggesting a predominant common source of deformation.

the average horizontal precision calculated for each benchmark is of $1.1 \mathrm{~cm}$ and the vertical average precision is of $0.8 \mathrm{~cm}$.

\subsubsection{Displacements between March and May 2007}

Between March and May 2007, the summit of Piton de la Fournaise experienced a progressive pre-eruptive outward inflation, additional uplift related to a dyke intrusion, and the caldera collapse. The permanent GPS network of the OVPF/IPGP clearly shows that the initial outward deformation was of minor importance with respect to the eastward dyke intrusion and much less than that measured during the caldera collapse (Peltier et al., 2009-this issue). Hence, most of the displacements inferred from our GPS campaigns in March and May 2007 result from the collapse event. Only the easternmost benchmarks are significantly influenced by the 30th March intrusion.

Our GPS data clearly show the large centripetal deformation related both to magma chamber deflation and the collapse event (Fig. 4b). When excluding the easternmost data points, which were also affected by the 30th March dyke intrusion that led to the opening of eruptive fissures SE of the cone (Fig. 1b), the displacement values range between 31 and $253 \mathrm{~cm}$ (Fig. 4a). It is likely that the latter value, which strongly differs from the surrounding ones, results from the displacement of an isolated block. The largest surface displacements are located on the southern caldera rim, where values higher than $130 \mathrm{~cm}$ are reached close to the caldera wall. Our data also exhibit a sharp decrease of the displacements $(-38$ to $-61 \%$ ) in the first two hundred metres from the northern and southern caldera edge. Such differences, which suggest the occurrence of extensional stresses on the proximal caldera rim, can be correlated with the location of the new concentric fractures, i.e. in a narrow zone around the western half of the caldera (Fig. 2a). Additional information can be found in the direction of the displacement vectors, which indicate the approximate location of the deflation source (Walsh and Decker, 1971). Here, the overall displacements suggest a deflation source elongated along a N75 axis that corresponds to the direction of elongation of the preexisting Dolomieu and of the 6th April initial collapse (Fig. 2a).

The comparison of the horizontal and vertical components of displacement provides further information that can be used to better constrain the geometry of the deflation source (Dieterich and Decker, 1975). GPS data show that the summit deflation led mostly to horizontal displacements (Figs. 4c and 5). For every benchmark, the ratio between horizontal and vertical displacements, the $H / V$ ratio, is always higher than 1 (Fig. 5). It shows a remarkably linear distribution with an average value around 2 , confirming that most of the benchmark displacements measured between March and May result from a similar, and likely a single origin, i.e. the syn-collapse deflation. The GPS network of the OVPF/IPGP also recorded predominant horizontal displacements at the base of the cone (Peltier et al., 2009this issue). Despite lateral variations between the western and eastern parts, along each transect, the closer to the caldera edge, the lower the $H$ / $V$ ratios (Fig. 5). Then, with the exception of the caldera walls, which suffered mostly vertical displacements, the central cone of Piton de la Fournaise experienced a predominant centripetal "horizontal collapse".

\subsubsection{Displacements between May and November 2007}

The GPS network has been reoccupied in November 2007 in order to identify post-collapse subsidence. Data show that during the 6 month-long period, the caldera rim continued to slightly subside (Fig. 6). According to Staudacher et al. (2009-this issue), 95\% of the post-collapse deformation occurred during the first 3 months and the remaining $5 \%$ during July to November 2007 . The distribution of the displacements for the period between May and November 2007 differs from that of the period between March and May 2007. The direction of the displacement vectors and the distribution of the largest displacements around the western half of the collapse caldera, could suggest a deflation source located below the western half of the caldera (Fig. 6). However, it cannot be excluded that the difference in the deformation pattern results from local deformation. It is noteworthy that the latest caldera wall destabilisations only occurred along the western scarps, where the inward displacements were still significant. Contrary to the $H / V$ ratios for the period between March and May 2007, which show important lateral variations, the $H / V$ ratios for the period between May and November 2007 present a homogeneous spatial distribution with values lower close to the caldera edge than at the distal extremity of the transects (Fig. 6c). This suggests an identical deformation style all around the caldera, which is independent of the amount of deformation. In consequence, our GPS data provides information both on the source and the mode of deformation. 

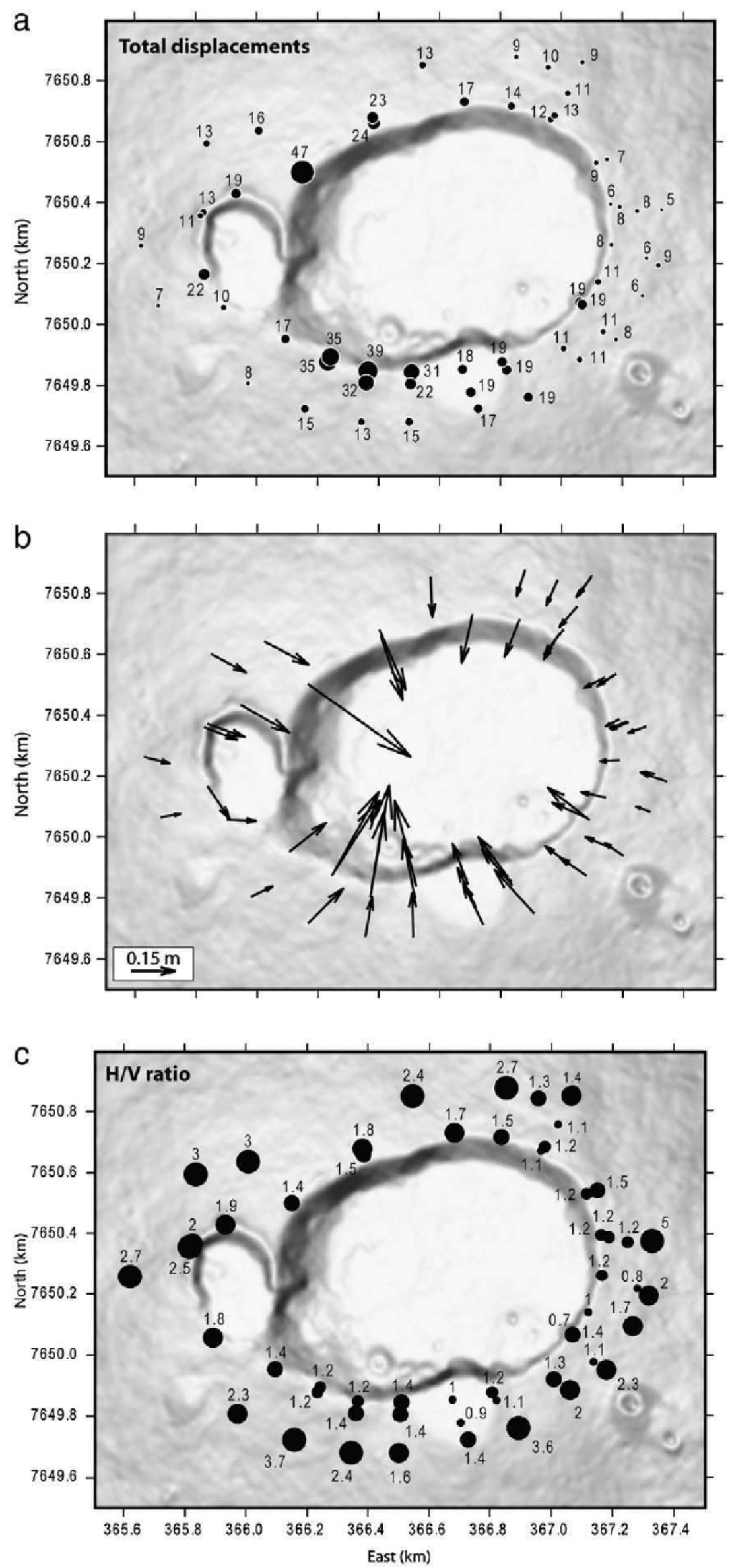


\section{Discussion}

\subsection{Origin of the concentric fractures around basaltic calderas}

Concentric fractures consist of extensional structures that are commonly observed around calderas. For example, at Erta 'Ale, (1) they are found within $20-60 \mathrm{~m}$ of the caldera rim, (2) their distance from the rim increases with the height of the caldera scarps, and (3) their opening width tends to increase when they are nearer to the rim (Acocella, 2006). Their development is consequently interpreted in terms of gravitational destabilisation of the caldera walls after the collapse (Acocella, 2006). At Fernandina, a similar fracture network has been observed around the caldera after the 1968 collapse (Simkin and Howard, 1970). Fractures are present on the rim $500 \mathrm{~m}$ from the edge and their density and size increase approaching the edge. Contrary to Erta 'Ale, the fracture network is interpreted as resulting from the collapse event (Simkin and Howard, 1971). These different interpretations of similar fracture networks raise the question of the multiple origins of the concentric fractures. Considering the concentric fracture network of Piton de la Fournaise, we propose several mechanisms that lead to the development or reactivation of concentric fractures.

1- The analysis of the fracture network before and after the April 2007 caldera collapse of Piton de la Fournaise reveals that concentric fractures do form on the caldera rim during collapse events. At Piton de la Fournaise, they are restricted to a few tens of metres of the caldera edge. A combination of GPS and structural data indicates that their formation is related to extensional stresses, which affected the proximal part of the caldera rim. They developed essentially south of the caldera where the sub-vertical part of the walls is of a few tens of metres (Fig. 2). The lack of correlation between the fracture density and the height of the caldera walls suggests that most of the extensional stresses do not result from local gravitational effects. This process can however not be entirely ruled out, specifically for the nearest fractures of the caldera edge. In consequence, we propose that most of the new concentric fractures result from extensional stresses that affect the proximal part of the caldera rim during the inward tilt of the caldera floor during successive collapses of the rock column. Such a mechanism is supported by the spatial correlation between the densest fracture zone and the tilted blocks around and into the southern half of the caldera. The development of the new fracture network was coeval with the reactivation of the pre-existing concentric fractures, which were the closer to the edge (Fig. 3).

2- Concentric fractures form at the limit of paleo-collapsed structures such as Petit Plateau and the western paleo-pit crater (Fig. 1d). The concentric fractures around these paleo-collapsed structures could result from a progressive subsidence due to compaction of the formations that filled the depression. However, $90-95 \%$ of the filling is composed of massive lava bodies that can hardly be compacted and the upper lava unit, which flowed outside the crater, is also affected by the concentric fractures. We propose that the whole paleo-collapsed structures may slightly subside during later collapses, triggering the development of circumferential extensional fractures above their hidden limits. Such a mechanism is suggested by our GPS data, which show for the period between March and May 2007 vertical displacements of the benchmarks located above the Petit Plateau paleo-pit crater between 20 and $40 \%$ greater than those outside the structure.

3- Finally, concentric fractures are reactivated during the progressive filling of the caldera. This process has been clearly observed during the August 2006-January 2007 summit eruption, during which concentric fractures progressively opened while lava accumulated within Dolomieu. It is likely that the extensional stresses that favour the fracture reactivation in a narrow zone around the caldera result from the increased weight of lava accumulated in the collapsed structure.

In summary, our observations of the concentric fractures between August 2006 and November 2007 allowed us to distinguish three mechanisms of fracture formation and reactivation. Contrary to Acocella (2006), we doubt that gravitational instabilities of the caldera wall explain the development of an entire concentric fracture network. The similarities between the fracture networks around the April 2007 caldera of Piton de la Fournaise and the caldera of Erta 'Ale rather suggest that the concentric fractures at Erta 'Ale may result from extension stresses related to the caldera collapse and maybe to the progressive filling of the caldera.

\subsection{Origin and dynamics of caldera collapse}

The geometry of caldera ring faults and the conditions required to promote a caldera collapse have been intensively studied during the last decades (e.g. Marti et al., 1994; Gudmundsson, 1998; Acocella et al., 2000; Roche et al., 2000, 2001; Roche and Druitt, 2001; Walter and Troll, 2001; Folch and Marti, 2004; Acocella, 2007). However, very few dealt with the dynamics of the collapse, i.e. continuous collapse or pulsating collapse, although the related magma deposits (Rosi et al., 1996; Reubi and Nicholls, 2004) and monitoring data (Filson et al., 1973; Kumagai et al., 2001) show contrasting behaviours. We compare, in what follows, the deformation and seismic data monitored during the caldera collapses of Fernandina, 1968, Miyakejima, 2000 and Piton de la Fournaise, 2007, in order to (1) stress the similarities between each event and consequently (2) determine a unifying mechanism that explains the different dynamics of caldera collapse.

Deformation data at Miyakejima and Piton de la Fournaise show that the caldera collapses have been preceded by an inward deflation of the edifice (Ukawa et al., 2000; Michon et al., 2007; Staudacher et al., 2009-this issue). The seismicity, which was characterised by frequent volcano-tectonic (VT) events before the onset of the subsidence, drastically changed once Miyakejima and Piton de la Fournaise started to deflate. The VT events disappeared and a low-frequency seismic signal progressively increased (Ukawa et al., 2000; Michon et al., 2007). The initial deflation phase ended by a sudden outward uplift of the edifice coeval with a magnitude 3.2 VT event at Piton de la Fournaise and a very-long-period event at Miyakejima (Kumagai et al., 2001; Michon et al., 2007). Afterwards, the edifices experienced identical deformation patterns with a succession of cycles characterised by a progressive deflation immediately followed by a sudden uplift (Fig. 7a). The deformation cycles were contemporaneous with a pulsating seismic signal (Kumagai et al., 2001; Michon et al., 2007). At Piton de la Fournaise, every cycle was characterised by a progressive amplification of the seismic signal, which then suddenly decreased to a low level (Fig. 7b). The periodicity of the cycles gradually increased from $2 \mathrm{~h}$ to $30 \mathrm{~min}$. Among the 38 cycles, only the two earliest ones were ended by large volcano-tectonic events (Michon et al., 2007). At Miyakejima, the seismicity evolved during each deformation cycles from an increasing swarm-like activity of low-frequency earthquakes coeval with the progressive deflation, up to very-long-period seismic events during the outward uplift (Ukawa et al., 2000; Kumagai et al., 2001). The cyclic distribution of the seismicity at Piton de la Fournaise and Miyakejima shows striking similarities with the seismicity monitored by a regional seismic network mostly distributed in North and South America during the 1968 caldera collapse of Fernandina. Indeed, the caldera formation was coeval with the occurrence of 30 earthquakes, the magnitude of which exceeded 4.5 (Fig. 7b; Filson et al., 1973). Each main event was preceded by an increase of the seismicity and followed by an almost aseismic period. This distribution consequently suggests the existence of seismic cycles whose duration progressively decreased from $6 \mathrm{~h}$ to $2 \mathrm{~h}$. Note that the largest earthquakes, $M_{\mathrm{s}}>5$, appeared during the first seismic cycles 

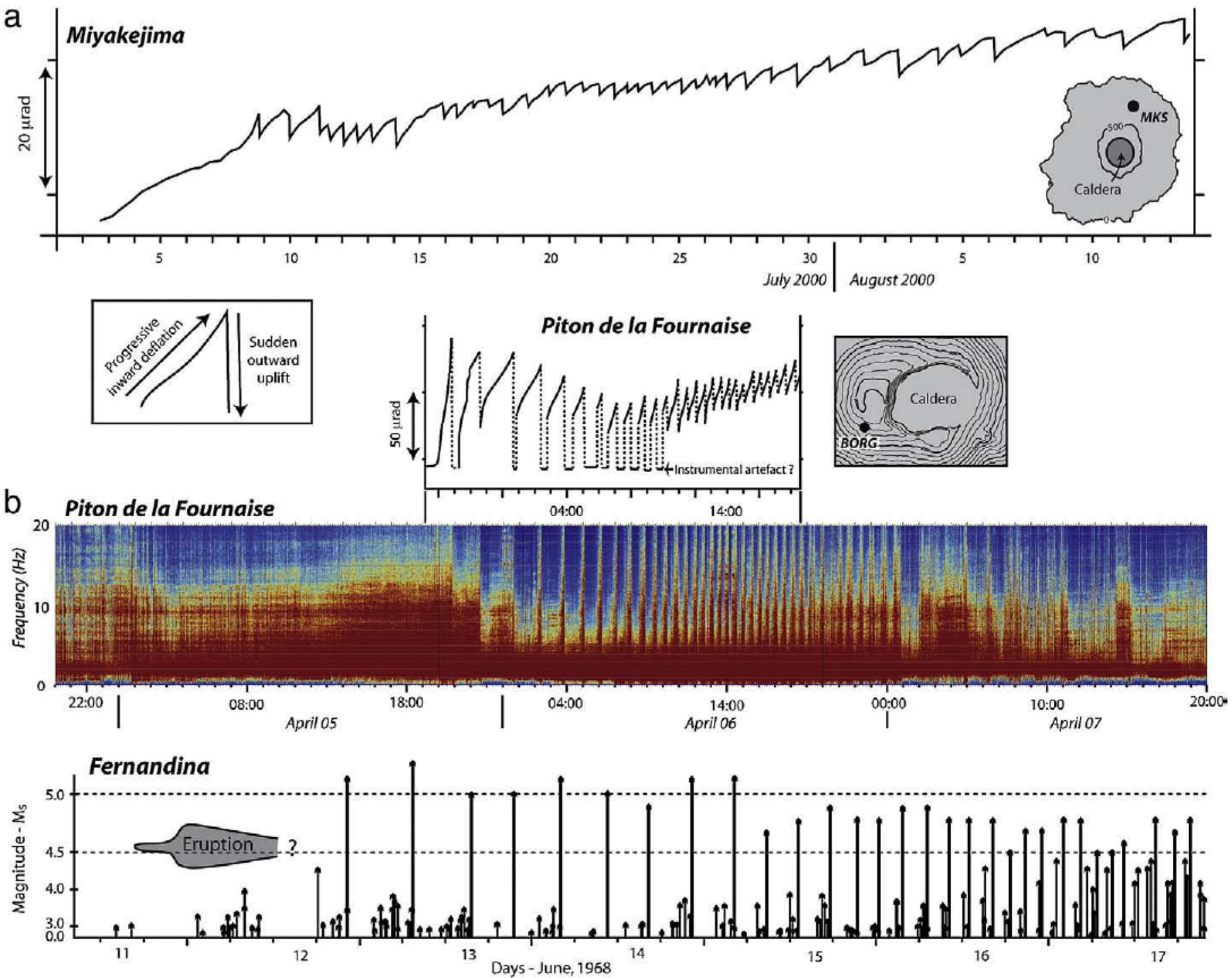

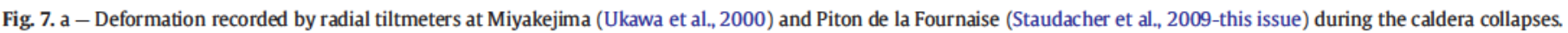

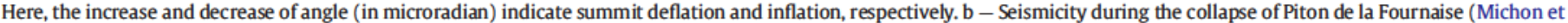
al., 2007) and Fernandina (Filson et al., 1973). See text for discussion.

(Fig. 7b). Despite differences in the type of seismic signal (VT or verylong-period events) that may originate from the geometry of the ring faults and the type of seismic networks, this overview of both the seismicity and the deformation recorded at Fernandina, Miyakejima and Piton de la Fournaise strongly suggests that each caldera collapse occurred in a similar way.

It has already been proposed that the main earthquakes at Fernandina, the very-long-period events at Miyakejima and the sharp decreases of the seismic signal at Piton de la Fournaise originate from the incremental collapse of the rock column into the magma chamber (Simkin and Howard, 1970; Filson et al., 1973; Kumagai et al., 2001; Michon et al., 2007). Although the periodicity is an obvious common feature, its origin has been interpreted in different ways for each volcano. The periodic very-long-period events and collapses at Miyakejima have been considered as to be caused by the constant magma outflow, which episodically sucked the rock column into the magma reservoir (Kumagai et al., 2001). At Fernandina, the irregular geometry of the bottom of the collapsing rock column (Filson et al., 1973) and the regular stress built up along the caldera fault, which is sporadically relieved by movement along the ring fault (Simkin and Howard, 1970), are two different mechanisms that have been proposed to explain the step by step collapse.
Combining the different characteristics of the caldera collapses at Fernandina, Miyakejima and Piton de la Fournaise, we put forward a unifying mechanism of basaltic caldera formation. We focus our discussion on calderas related to magma withdrawal from a magma chamber during eruptions or intrusions. Calderas formed by the deformation of the hydrothermal system (e.g. Merle and Lénat, 2003; Merle et al., 2006) are consequently not addressed in this paper.

First of all, the deformation of the summit of basaltic volcanoes is intimately linked to large lateral eruptions or magma intrusions (MacDonald, 1965). Natural examples of Piton de la Fournaise and Miyakejima reveal that calderas may develop over times of days to weeks during or after the magma withdrawal (Geshi et al., 2002; Wright and Sakai, 2004; Michon et al., 2007). The pressure decrease into the magma chamber caused by the magma withdrawal entails, above all, the centripetal subsidence of the edifice (Fig. 8b). The continuous inward deflation progressively changes the stress within the edifice. Despite the pressure decrease within the magma chamber, the centripetal deflation prevents the downward motion of the rock column due to gravitational stress by increasing both the shear stress $\tau$ opposite to the collapse and the shear strength along the pre-existing ring faults, which are common on long-lived volcanoes (Fig. $8 \mathrm{~b}$ ). The collapse of the rock column occurs when the difference between the 

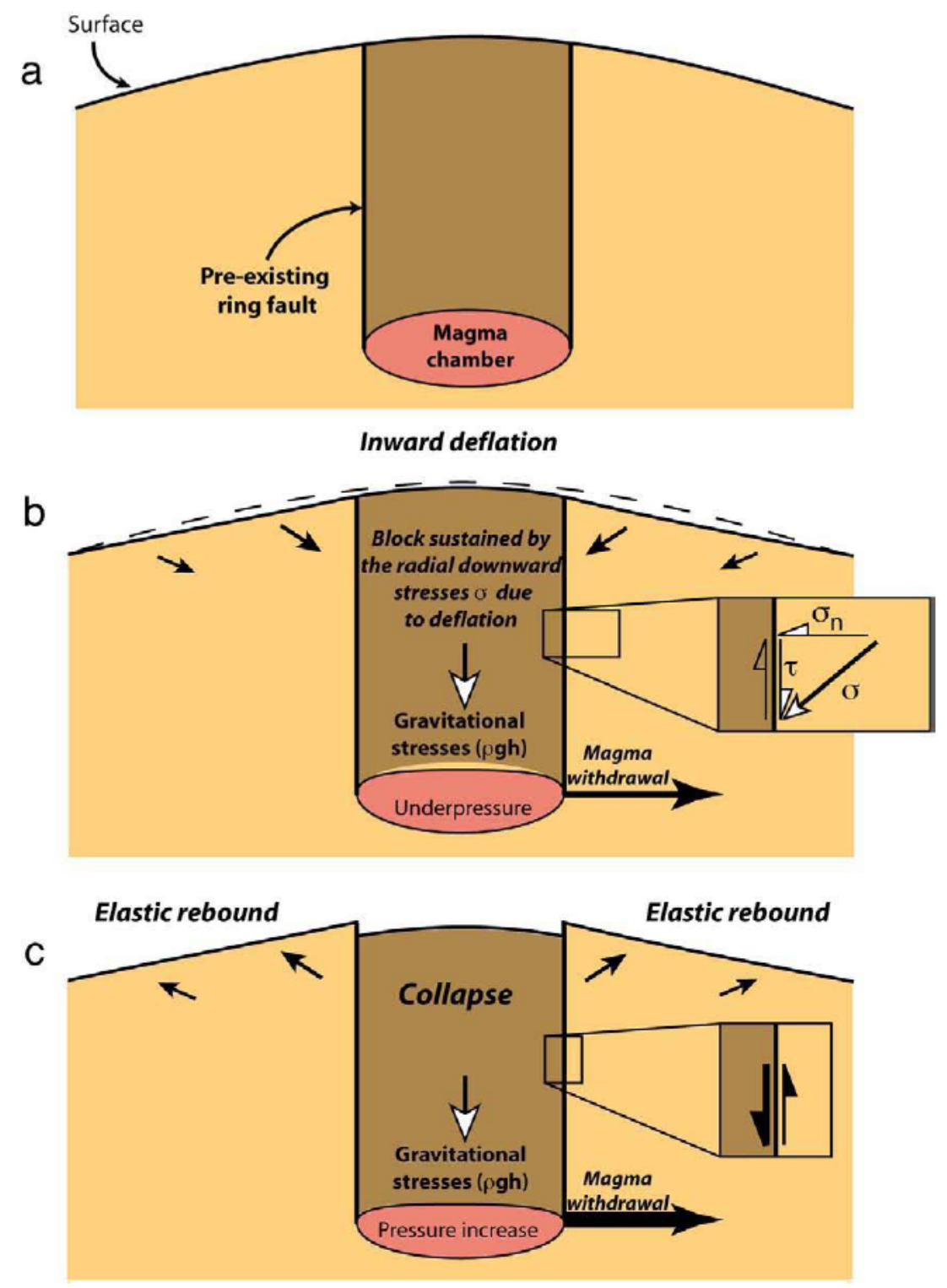

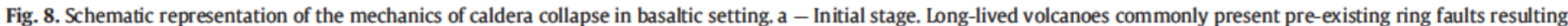

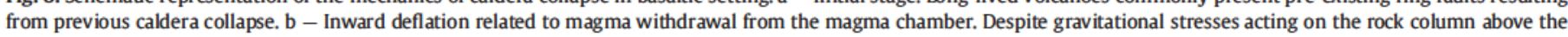

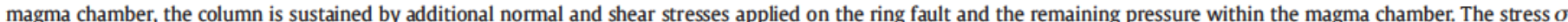

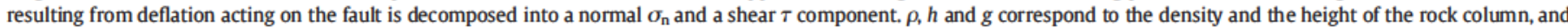

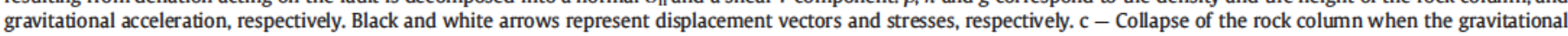

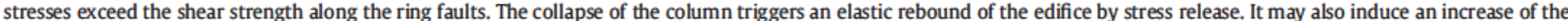

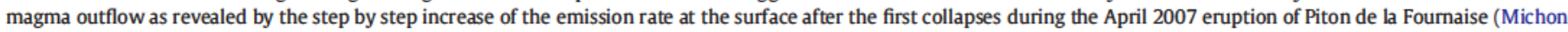
et al., 2007). Each cycle is subsequently characterised by the succession of step b (inward deflation) and c (collapse and outward uplift).

gravitational stress and the pressure within the magma chamber is sufficient so that the shear strength of the ring faults is exceeded (Fig. $8 \mathrm{c})$. Then, the downward displacement stops when the pressure increase into the magma chamber sustains the rock column anew.

We showed above that every collapse at Piton de la Fournaise and Miyakejima were coeval with outward uplift of the caldera rim. Such displacements were interpreted for Miyakejima as resulting from the expansion of the magma chamber when the rock column intrudes it (Kumagai et al., 2001). Although this hypothesis cannot be ruled out, we prefer the following alternative explanation. The immediate, short outward deformation of the caldera rim after the collapse corresponds to the elastic response of the edifice, when the downward stress is sporadically released during the motion of the rock column. The ongoing subsidence, which directly results from the magma withdrawal, promotes a new stress increase along the ring fault and prevents the collapse of the rock column. The collapse occurs anew when the shear strength is overcome by the gravitational stress exerted on the rock column. Each cycle is consequently characterised by the succession of (1) a deflation phase which inhibits the downward displacement of the rock column, and (2) a sudden collapse when the gravitational stress exceeds the shear strength along the faults. The duration between two collapses may be influenced by the injection of magmatic fluids along the ring faults. In such a case, their shear resistance declines (Anderson, 1951; Hubbert and Rubbey, 1959) and the time span between two collapses could therefore decrease like at Fernandina and Piton de la Fournaise for a constant or increasing magma withdrawal, and increase if the rate of magma outflow decreases. Recently Wright and Sakai (2004) proposed that calderas develop only following high rates of magma withdrawal. Following Druitt and Sparks (1984), Martí et al. (2000), Roche and Druitt (2001), Geyer et al. (2006), we think that the amount of magma withdrawal is the critical parameter that initiates 
caldera formation. To this respect, one can note that the February and December 2005 lateral eruptions of Piton de la Fournaise, which shows similarities with the April 2007 eruption in terms of location of the eruption site and nature of magma, but a volume of magma one order of magnitude less important $\left(15-20 \cdot 10^{6} \mathrm{~m}^{3}\right.$ in 2005 and about $130 \cdot 10^{6} \mathrm{~m}^{3}$ in April 2007; Staudacher et al., 2009-this issue), triggered a slight summit subsidence only (Peltier, 2007). Besides the volume of withdrawn magma, the occurrence of a caldera collapse is likely influenced by the strength of the edifice, the occurrence and geometry of pre-existing ring faults, the depth and size of the magma chamber (e.g. Acocella, 2007).

At Piton de la Fournaise, the step by step increase of both the tremor and the emission rate at the eruption site, after the first collapses, indicates that the rock column directly affected the magma chamber by increasing the pressure into the magma reservoir (Michon et al., 2007). Each collapse was accompanied by an ash plume composed of lithics solely above the summit (Staudacher et al., 2009-this issue). The simultaneity between deep and surface processes suggests a continuum of deformation from the roof of the magma chamber up to the surface. The collapse of such a piston-like rock column may explain the predominance of the horizontal component at both the base of the cone and the summit, where $H / V$ values are around 2 for the period between March and April 2007. According to Dieterich and Decker (1975), such a displacement pattern is better explained by a vertically elongate axisymmetric source of deformation. This deflation source could correspond to the piston-like rock column that progressively moved downward. Hence, we propose that the predominantly horizontal centripetal deformation of the edifice results from the vertical motion of the piston-like column that allowed the "horizontal collapse" of the edifice.

This synthesis on the three best known basaltic calderas suggests that when the magma withdrawal-related inward subsidence is sufficiently advanced, the rock column between the magma chamber and the surface, intermittently collapses. We propose that the pulsating dynamics were resulting from a competition between deflation, which prevents the collapse, and gravity exerted on the block, which makes it possible despite deflation. It is noteworthy that pulsating eruption dynamics have also been proposed for several silicic calderas (Rosi et al., 1996, 1999; Troll et al., 2000; Reubi and Nicholls, 2004). This dynamic was mostly interpreted in terms of piecemeal caldera collapses. We assume that the collapse mechanism determined for basaltic calderas can be applied to silicic eruptions. The type of collapse, i.e., intermittent or continuous, would be then influenced by the emission rate. In summary, the volume and the rate of magma withdrawal would control the collapse initiation and dynamics, respectively.

\subsection{Geometry of the collapse at Piton de la Fournaise}

Carter et al. (2007) recently proposed that the magma chamber associated with the recurrent collapses of Dolomieu, before the April 2007 eruption, was located at around $1000 \mathrm{~m}$ below the surface, i.e. $1500 \mathrm{~m}$ asl. However, inversions of deformation data, GPS and interferometry, related to the eruptions of Piton de la Fournaise strongly suggest that dykes originate from a magma reservoir lying between 0 and $800 \mathrm{~m}$ asl (Fukushima et al., 2005; Peltier et al., 2007). Assuming that magma withdrawal from this magma chamber triggered the April 2007 caldera collapse, the aspect ratio of the caldera system, which corresponds to the depth versus width of the magma reservoir (Roche et al., 2000), is about 2. Analogue models indicate that for high aspect ratios multiple reverse faults break up the roof into large pieces and subsidence occurs as a series of nested cones (Roche et al., 2000, 2001). However, at Piton de la Fournaise, as at Miyakejima where the aspect ratio is also high (Geshi et al., 2002), the pulsating dynamics of the collapse rather suggests that the collapsed rock column behaved as a coherent block (Kumagai et al., 2001). We propose that the geometry differences between models and nature are mainly due to the presence of pre-existing ring faults in nature, whereas models are composed of isotropic materials.

On 6th April, 2007, the first observations of the caldera at Piton de la Fournaise indicated the occurrence of a first elongated collapse structure bounded by sub-vertical scarps (Michon et al., 2007). The presence of preserved polished surfaces on the scarps (Fig. 2b) suggests that the subsidence was controlled by inward steep normal faults in sub-surface (Fig. 9b). Considering the usual development of steep outward reverse faults in analogue models (e.g., Marti et al., 1994), we propose that the base of these inward faults is connected to outward dipping reverse faults, which are vertical at depth. The remaining southern and eastern plateaus subsequently collapsed on a

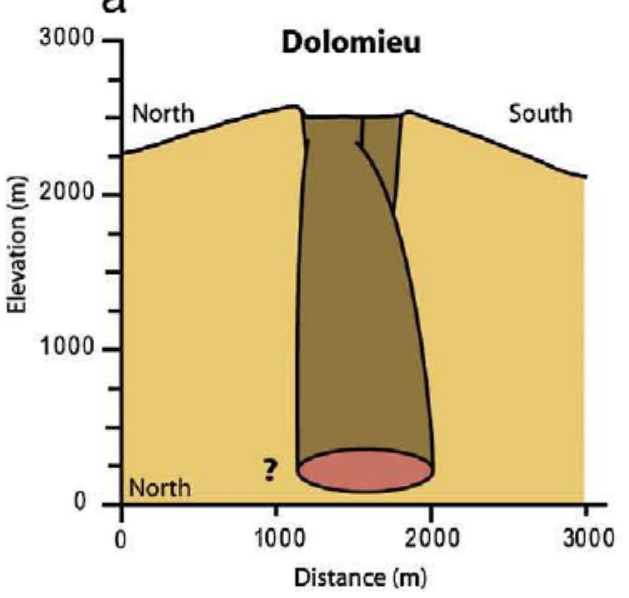

b

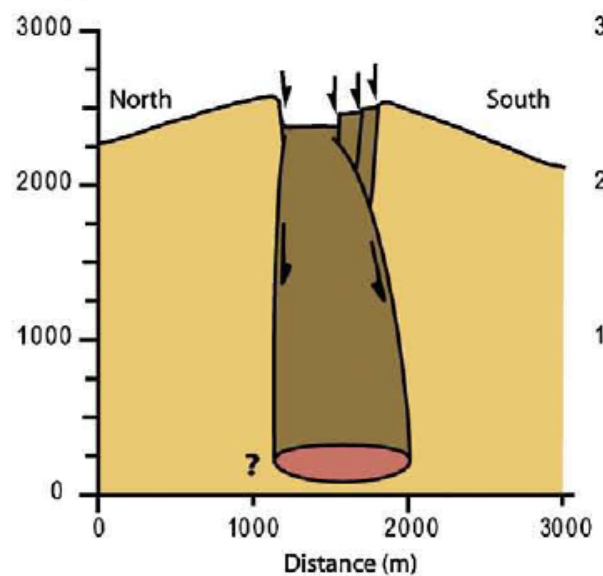

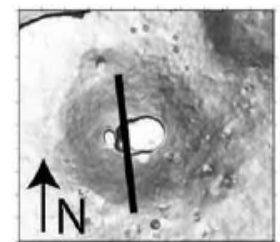

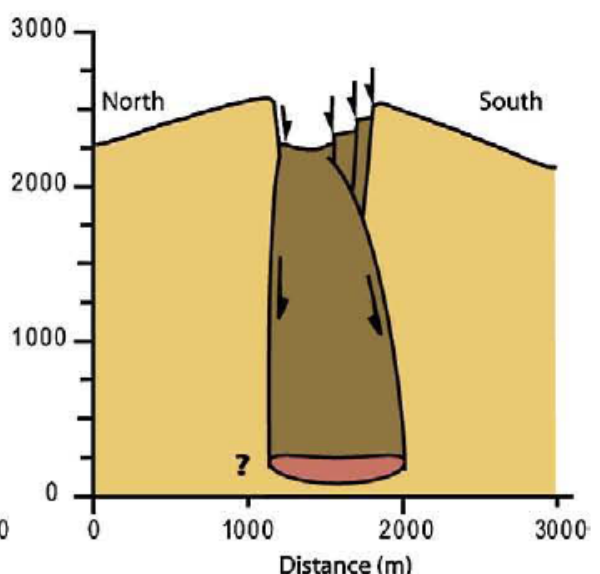

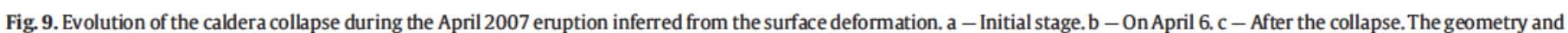
depth of the magma chamber is still poorly constrained. 
7th April (see Fig. 4 in Michon et al., 2007). Their inward collapse can be usefully compared to the tilting blocks, which develop on analogue models between the central collapse and the outer normal ring faults (Roche et al., 2000, 2001; Acocella, 2007). Hence, the pre-existing southern and eastern boundaries of Dolomieu were probably reactivated in normal faulting mode (Fig. 9c). The inward deformation related to the tilt of the southern plateau probably affected the southern rim of the caldera as suggested by the occurrence of maximal inward displacements along its southern limit for the period between March and May 2007. Thus, the spatial correlation between the densest fracture zone, the maximal displacements of the caldera rim and the inward tilt of the southern plateau into the caldera suggests that the displacements recorded by GPS result from both a general deflation due to the magma withdrawal from the magma chamber and local effects due to the caldera collapse. Besides the clear control of pre-existing structures in the April 2007 collapse, the similar geometry of Dolomieu before and after the collapse suggests that the source of the collapse, i.e. the magma chamber, did not significantly change during the last hundred years.

\section{Conclusion}

We implemented in November 2005 a new GPS network around the summit collapsed structure of Piton de la Fournaise in order to determine the deformation related to collapse events. The present work clearly shows that the network allowed a precise determination of the summit deformation during and after the April 2007 caldera collapse. Moreover, combining GPS data and a structural analysis, we highlight the relationship between the inward displacements, the development of concentric fractures and the dynamics of collapse.

The paper also presents several sources leading to the formation of concentric fractures. Concentric fractures, which are restricted to the first tens of meters of the caldera edge result from extension stresses that are related to (1) the inward tilt of the caldera floor during the successive collapses of the rock column, (2) the reactivation of hidden limits of paleo-collapsed structures and (3) the progressive replenishment of the caldera by lava flows, the load causing a local downsag.

The seismicity and deformation data for the caldera collapses at Fernandina, 1968, Miyakejima, 2000, and Piton de la Fournaise, 2007, suggest a similar pulsating collapse mechanism. Taking into account the stress evolution into the edifice, we propose a unifying model of caldera collapse in basaltic setting that explains the cyclic deformation. The pulsating dynamics result from a competition between deflation, which prevents the collapse, and gravity exerted on the rock column above the magma chamber, which makes it possible despite deflation.

Finally, the structure of the new caldera of Piton de la Fournaise and its evolution during the collapse is explained by the collapse of a coherent block limited by vertical to outward dipping faults at depth and sub-surface normal faults. The similar contours of Dolomieu before the collapse and of the new caldera, remarkably shows the control of the pre-existing structures in the April 2007 caldera collapse.

\section{Acknowledgments}

The authors warmly thank Aline Peltier, Vincent Famin, Anthony Finizola and Isabelle Basile-Doelsh for participating to the network implementation and GPS campaigns. The paper benefited from the comments of Olivier Roche and Tom Wright. The Piton de la Fournaise Volcano Observatory kindly provided data of the permanent GPS receivers. The authors thank Ruth Andrew for improving an initial version of the manuscript. This is IPGP contribution \#2414.

\section{References}

Acocella, V., 2006. Regional and local tectonics at Erta Ale caldera, Afar (Ethiopia). J. Struct. Geol. 28, 1808-1820.

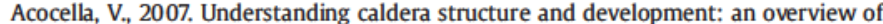
analogue models compared to natural calderas. Earth-Sci. Rev. 85, 125-160.

Acocella, V., Cifelli, F., Funiciello, R., 2000. Analogue models of collapse calderas and resurgent domes. J. Volcanol. Geotherm. Res. 104, 81-96.

Anderson, E.M., 1951. The dynamics of faulting. Trans. Edinb. Geol. Soc. 8, 387-402.

Bachèlery, P., 1981. Le Piton de la Fournaise (Ile de la Réunion). Etude volcanologique, structurale et pétrologique. PhD thesis, Univ. Clermont-Ferrand II, 215pp.

Beauducel, F, Agung Nandaka, M., Cornet, F.H., Diament, M., 2006. Mechanical discontinuities monitoring at Merapi volcano using kinematic GPS. J. Volcanol. Geotherm. Res. 150, 300-312.

Branney, J.M, 1995. Downsag and extension at calderas: new perspectives on collapse geometries from ice-melt, mining, and volcanic subsidence. Bull. Volcanol. 57, 303-318.

Carter, A., van Wyk de Vries, B., Kelfoun, K., Bachèlery, P., Briole, P., 2007. Pits, rifts and slumps: the summit structure of Piton de la Fournaise. Bull. Volcanol. 69, 741-756. doi: $10.1007 /$ s00445-006-0103-4.

Dieterich, J.H., Decker, R.W., 1975. Finite element modeling of surface deformation associated with volcanism. J. Geophys. Res. 80, 4094-4102.

Druitt, T.H., Sparks, R.S.J., 1984. On the formation of calderas during ignimbrite eruptions. Nature 310, 679-681.

Filson, J., Simkin, T., Leu, L-K., 1973. Seimicity of a caldera collapse: Galapagos Islands 1968. J. Geophys. Res. 78, 8591-8622.

Folch, A., Marti, J., 2004. Geometrical and mechanical constraints on the formation of ring-fault calderas. Earth Planet. Sci. Lett. 221, 215-225.

Fukushima, Y., Cayol, V., Durand, P., 2005. Finding realistic dike models from interferometric synthetic aperture radar data: the February 2000 eruption at Piton de la Fournaise. J. Geophys. Res. 110, B03206. doi:10.1029/2004JB003268.

Geshi, N., Shimano, T., Chiba, T., Nakada, S., 2002. Caldera collapse during the 2000 eruption of Miyakejima Volcano, Japan. Bull. Volcanol. 64, 55-68.

Geyer, A., Folch, A., Marti, J., 2006. Relationship between caldera collapse and magma chamber withdrawal: an experimental approach. J. Volcanol. Geotherm. Res. 157, 375-386.

Gudmundsson, A., 1998. Formation and development of normal-fault calderas and the initiation of large explosive eruptions. Bull. Volcanol. 60, 160-170.

Hirn, A., Lépine, J.-C., Sapin, M., Delorme, H., 1991. Episodes of pit-crater collapse documented by seismology at Piton de la Fournaise. J. Volcanol. Geotherm. Res. 47, 89-104.

Hubbert, M.K., Rubbey, W.W., 1959. Role of fluid pressure in mechanics of overthrust faulting. Bull. Geol. Soc. Am. 70, 115-166.

Ito, T., Yoshioka, S., 2002. A dike intrusion model in and around Miyakejima, Niijima and Kozushima in 2000. Tectonophysics 359, 171-187.

Kumagai, H., Ohminato, T., Nakano, M., Ooi, M., Kubo, A., Inoue, H., Oikawa, J., 2001. Very-long-period seismic signals and the caldera formation at Miyake Island, Japan. Science 293, 687-690.

Lacroix, A., 1939. Les transformations récentes du sommet du volcan actif (Piton de la Fournaise) de l'Ile de la Réunion. Bull. Volcanologique, serie II tome V, pp. 3-18.

Lénat, J.-F., Bachèlery, P., 1987. Dynamics of magma transfer at Piton de la Fournaise volcano (Réunion Island, Indian Ocean). In: Chi-Yu, Scarpa (Eds.), Modeling of Volcanic Processes. Friedr. Vieweg and Sohn, Brauschweig/Wiesbaden, pp. 57-72.

Lénat, J.-F., Bachèlery, P., 1990. Structure and dynamics of the central zone of Piton de la Fournaise volcano. In: Lénat, J.-F. (Ed.), Le volcanisme de la Réunion, Monographie. Cent. De Rech. Volcanol., Clermont-Ferrand, pp. 257-296.

Longpré, M.-A., Staudacher, Th., Stix, J., 2007. The November 2002 eruption at Piton de la Fournaise volcano, La Réunion Island: ground deformation, seismicity, and pit crater collapse. Bull. Volcanol. 69, 511-525. doi:10.1007/s00445-006-0087-0.

MacDonald, G.A., 1965. Hawaiian calderas. Pac. Sci. 19, 320-334.

Marti, J., Ablay, G.J., Redshaw, L.T., Sparks, R.S.J., 1994. Experimental studies of collapse calderas. J. Geol. Soc. (Lond.) 151, 919-929. doi:10.1144/gsjgs.151.6.0919.

Martí, J., Folch, A., Macedonio, G., Neri, A., 2000. Pressure evolution during calderaforming eruptions. Earth Planet. Sci. Lett. 175, 275-287.

Merle, O., Lénat, J.-F., 2003. Hybrid collapse mechanism at Piton de la Fournaise volcano, Reunion Island, Indian Ocean. J. Geophys. Res. 108, 2166. doi:10.1029/2002JB002014.

Merle, O, Barde-Cabusson, S., Maury, RC., Legendre, C., Guille, G., Blais, S., 2006. Volcano core collapse triggered by regional faulting. J. Volcanol. Geotherm. Res. 158, 269-280.

Michon, L, Staudacher, Th., Ferrazzini, V, Bachèlery, P., Marti,J., 2007. April 2007 collapse of Piton de la Fournaise: a new example of caldera formation. Geophys. Res. Lett. 34, L21301. doi:10.1029/2007GL031248.

Michon, L, Cayol, V., Letourneur, L., Peltier, A., Villeneuve, N., Staudacher, T., 2009. Edifice growth, deformation and rift zone development in basaltic setting: Insights from Piton de la Fournaise shield volcano (Réunion Island). J.Volcanol. Geotherm. Res. 184, 14-30 (this issue). doi:10.1016/j.jvolgeores.2008.11.002.

Mogi, K., 1958. Relations of the eruptions of various volcanoes and the deformations of the ground surfaces around them. Bull. Earthq. Res. Inst. Univ. Tokyo 36, 99-134.

Peltier, A., 2007. Suivi, modélisation et évolution des processus d'injections magmatiques au Piton de La Fournaise (Réunion), à partir d'une analyse croisée des données de déformation, géochimiques et structurales. PhD Thesis, Univ. Réunion, 282p. http:// tel.archivesouvertes.fr/index.php?halsid=gljus 7suihg3og6qn385016jn5\&view_this_doc $=$ tel-00167895\&version $=1$.

Peltier, A., Staudacher, Th., Bachèlery, P., 2007. Constraints on magma transfers and structures involved in the 2003 activity at Piton de La Fournaise from displacement data. J. Geophys. Res. 112, B03207. doi:10.1029/2006JB004379.

Peltier, A., Staudacher, T., Bachèlery, P., Cayol, V, 2009. Formation of the April 2007 caldera collapse at Piton de La Fournaise volcano: Insights from GPS data. J. Volcanol. Geotherm. Res. 184, 152-163 (this issue). doi:10.1016/j.jvolgeores.2008.09.009.

Ryan, M.P., Blevins, J.Y.K., Okamura, A.T, Koyanagi, R.Y., 1983. Magma reservoir subsidence mechanics: theoretical summary and application to Kilauea Volcano, Hawaii. J. Geophys. Res. 88, 4147-4181. 
Reubi, O., Nicholls, I.A., 2004. Variability in eruptive dynamics associated with caldera collapse: an example from two successive eruptions at Batur volcanic field, Bali, Indonesia. Bull. Volcanol. 66, 134-148. doi:10.1007/s00445-003-0298-6.

Roche, O., Druitt, T.H., 2001. Onset of caldera collapse during ignimbrite eruptions. Earth Planet. Sci. Lett. 191, 191-202.

Roche, 0, Druitt, T.H., Merle, 0., 2000. Experimental study of caldera formation. J. Geophys Res. 105, 395-416.

Roche, O., Van Wyk de Vries, B., Druitt, T.H., 2001. Sub-surface structures and collapse mechanisms of summit pit craters. J. Volcanol. Geotherm. Res. 105, 1-18.

Rosi, M., Vezzoli, L, Aleotti, P., De Censi, M., 1996. Interaction between caldera collapse and eruptive dynamics during the Campanian Ignimbrite eruption, Phlegraean Fields, Italy. Bull. Volcanol. 57, 541-554.

Rosi, M., Vezzoli, L., Castelmenzano, A., Grieco, G., 1999. Plinian pumice fall deposit of the Campanian Ignimbrite eruption (Phlegraean Fields, Italy). J. Volcanol. Geotherm. Res. 91, 179-198.

Simkin, T., Howard, K.A., 1970. Caldera collapse in Galapagos Islands, 1968. Science 169, 429-437.

Staudacher, T., Ferrazzini, V., Peltier, A., Kowalski, P., Boissier, P., Catherine, P., Lauret, F Massin, F., 2009. The April 2007 eruption and the Dolomieu crater collapse, two major events at Piton de la Fournaise (La Réunion Island, Indian Ocean). J. Volcanol. Geotherm. Res. 184, 126-137 (this issue). doi:10.1016/j.jvolgeores.2008.11.005.
Troll, VR, Emeleus, C.H., Donaldson, $\mathrm{CH}$., 2000. Caldera formation in the Rum Central Igneous Complex, Scotland. Bull. Volcanol.62, 301-317. doi:10.1007/s004450000099.

Troll, V.R., Walter, T.R., Schmincke, H.-U., 2002. Cyclic caldera collapse: piston or piecemeal subsidence? Field and experimental evidence. Geology 30, 135-138.

Ukawa, M., Fujita, E., Yamamoto, E., Okada, Y., Kikuchi, M., 2000. The 2000 Miyakejima eruption: crustal deformation and earthquakes observed by the NIED Miyakejima observation network. Earth Planets Space 52, xix-xxvi.

Urai, M, Geshi, N Staudacher, Th, 2007. Size and volume evaluation of the caldera collapse on Piton de la Fournaise volcano during the April 2007 eruption using ASTER stereo imagery. Geophys. Res. Lett. L22318. doi:10.1029/2007GL031551.

Walsh, J.B., Decker, R.W., 1971. Surface deformation associated with volcanism. J. Geophys. Res. 76, 3291-3302.

Walter, T.R., Troll, V.R., 2001. Formation of caldera periphery faults: an experimental study. Bull. Volcanol. 63, 191-203.

Wilson, R.M., 1935. Ground surface movement at Kilauea Volcano, Hawaii. Univ. Hawaii Res. Publ. 10 (56p.)

Wright, T.L., Sakai, S., 2004. Interpretation of the Miyakejima 2000 eruption and dike emplacement using time animations of earthquakes. Bull. Earthq. Res. Inst., Univ. Tokyo 79, 1-16. 